\title{
Interrogating Nollywood and its Sources of Funding: The Case of Invasion 1897
}

*Silver A. OJIESON

\begin{abstract}
The problem of funding continues to haunt start-ups in Africa and there seems to be no respite in sight as the government and other institutions with the requisite capacity to support entrepreneurial efforts are not committed to the course. Given this set back, Nigeriaôs Nollywood is encumbered by the problem of accessing sustainable funding sources for a vibrant entertainment and hospitality business where funding, which catalyses the efforts of independent producers, is hard to come by. In this way, inadequacy of internal funds by owners of independent production outfits leaves them constrained and unable to express their ideas to the fullest in terms of artistic dynamism and technical verve. Whilst debt funding and equity are other sources of funding available to production outfits, in the case of Nollywood where personal transactions are preferred instead of contracts and corporate entities limit the extent of professional dedication and commitment to each film project. Grounding this article on the pecking order theory, funding sources are interrogated by evaluating Invasion 1897 and Lancelot Oduwa Imasuenôs recourse to funding sources through the interview method. The article submits that sustainable sources of funding are obviously lacking on the Nollywood scape, making it difficult for indigenous producers to carry out their prospects of filmmaking. To forestall a breakdown of production apparatuses, the independent producers and corporate film outfits are encouraged to forge a synergy both within and outside the shores of Nigeria for greater productivity.
\end{abstract}

Keywords: Funding sources, Nollywood, Productions, Informal economy,

\footnotetext{
*Silver A. OJIESON of the Day Waterman College, Abeokuta-Ogun State Email: silverabhulimhen@gmail.co
} 


\section{Introduction}

Nollywood operates informally in the Nigerian economy with efforts of individual and joint ventures aimed at filmmaking. In spite of its long tortuous journey on the heels of colonial legacies, independent efforts and not corporate or government support has kept it afloat. This leaves much to be desired as the extent of monetary muscle power at stake is barely enough to cater for the exigent provision of theatrical elements required to birth a wellmade film. This state of financial lack and unavailability of sustainable sources of funding hampers the content and form taken by Nollywood productions. In the production culture of Hollywood, China, Britain, France, Germany, Canada, India and other established film hubs around the globe, corporate interests and government incentives supersedes individual efforts upon which Nollywood prides its enterprise. This brings us to the question of Nollywood funding and its viability, which given the present socio-economic straits bedeviling the economy has inherent demerits for the entrepreneur and debutant filmmaker. In the present circumstance, this brings to mind the need to calibrate the sources of Nollywood funding which is a prerequisite for productions. Whereas many filmmakers rely solely on their startups, it is quite disheartening to know that other sources exist that producers have not bothered to explore so as to facilitate a climate of continuous productions.

\section{Literature Review}

According to Aabi:

These enterprises often turn away from formal mechanisms and operate in the informal economy, riskily evading taxes and regulations. Besides, acute asymmetries of information, lack of reliable track records, reliance on collaterals and lack of equity etc. continues to impede the access to finances and particularly to debt financing. Today most companies are facing a clear downturn 
in demand of goods and services on one hand and a shortage of credit on the other, due to the tightening of financing by credit institutions. And, as all companies, SMEs need financial resources for their functioning and survival $(2014$, p. 2).

There is an apparent need to understand Aabiôs point of view above, especially where entrepreneurial efforts are cut off from formal entities with requisite ability to better its lot. In view of this, one understands that film production in Nigeria has not entered the mainstream economy. By this token, funding is done by individuals whose entrepreneurial skills guide their aspirations in continuously producing movies in spite of acute financial shortfall. The implication of this, which rubs off on the kind of movies made squarely depends on a filmôs budget. While it is common knowledge that there are no agencies funding films in Nigeria, government funding and all attempts in that direction are usually one-offs and the banks are not in any way obliged to put their money on any filmmaker.

A funding perspective on the historical undertone of production funding in Nigeria is essential as we look briefly into the account of Afolabi Adesanya, a one-time Director General of the Nigerian Film Institute/Film Corporation. This will set the tone on the funding metamorphosis which Nollywood has come to bear with after two decades of productive outings with corporate organizations. In a seminal reference on the Nigerian filmmakersô consolidation with corporate finance, it seems that indigenous filmmakers had a better rapport with the establishment. In this regard, Adesanya submits that, money and its purchasing power is an essential commodity for filmmaking:

Money. Money. Yet, none to produce filmò:

This has been the refrain of Nigerian aspiring and practicing filmmakers since the emergence of local film producers. But is this true? Is it that Nigerian filmmakers lack financial goodwill? Or is it that Nigerian 
filmmakers, inspire and instil (sic) a sense of confidence in the financial sector? Are Nigerian filmmakers fly-by-night producers? $(1990, \mathrm{p} .1)$

In Adesanyaôs bid to explain the enigma that is funding, he considers the financial drought experienced by indigenous filmmakers. However, seeing how much the Calpenny Film firm was able to attract from the financial sector, Adesanya is enthused that, if the local producers are committed to the course of a market driven film ethos, there was so much to achieve. Citing Armah (1987), Adesanya opines that Francis Oladele, famed for Kongi, Bullfrog and other films successfully raised $\mathrm{N} 3 \mathrm{~m}$ for the production of Oju Aiye (Eye of the World) through IMB Securities (a subsidiary of IMB). In his own words, Adesanya aver that:

This is a novelty in the annals of the Nigerian budding film industry. The venture capital issue was actually oversubscribed, but seven years later, the feature film is yet to be previewed by investors, and released for public viewing. The pioneer film producer is said to be asking his investors for additional funds to complete the film! That same year, the same financial house and $\mathrm{CMB}$ were approached to raise money for the production of A-PRODUCTIONSô debut feature VIGILANTTE. Neither came through (1990, p.1).

There is so much to consider in the epic sojourn of the Nigerian film industry when it went to the Stock Exchange Market. First, considering that 1986 and this period was the peak of indigenous cinemas in local film history, so much momentum had built up to this daring move to source funding, openly. Secondly, it demonstrates so much trust that the Nigerian audience, which had so much faith in the local content produced then, subscribed to the funding of Oju-Aiye. Thirdly, the concept of ócrowd Fundingôwas at play here, and without taking the notice for granted, displayed to 
the world, that Nigerians were patriotic in their demand for homemade entertainment. Fourthly, the confidence reposed in the Calpenny brand by the financial sector showed that so much collaboration was possible between indigenous companies and financial proprietors. Maybe, if this much touted move to take the Nigerian film into main stream economy had succeeded, the fate of the funding constraints bedevilling Nollywood would not be this harsh a reality to bear. Perhaps, the non-release of Oju-Aiye conditioned the modus operandi of the financial sector in such a way that future moves to solicit funding failed to yield requisite results as hinted in the case of A-ProductionsôVigilante.

Furthermore, Adesanya says that out of sheer determination to succeed and not minding the frustration associated with raising funds and being turned down by financial institutions, he forged ahead. After a long while, he was able to receive funding years later after proving his mettle, producing some works that were recognized. He says that:

In 1989, the company, now with a árack recordô was lucky to secure the goodwill of Rims Merchant Bank (and Wema Bank) to raise $\mathrm{N} 815,000$ for its production of OSE SANGO (SANGOòS WAND), in 1990 as a Debenture Stock as opposed to the uninsured venture capital issue. The film was released in 1990 and it immediately commenced paying back. It went on to win the maiden Hubert Ogunde Foundation award for THE BEST FILM.

It seems, from the above assertions, that early Nigerian filmmakers made frantic efforts to go ómain streamôas this was the most standard medium of accessing funding. This approach also made the corporate world see Nigerian filmmaking as a serious business capable of attracting requisite industrial relationship where current Nollywood begs for attention. These pockets of success stories are a reminder that, once upon a time, in Nigeria, the average filmmaker, against all odds, sought transparency and 
vied within their means, to conduct their trade in the competitive corridors of business transactions. Unlike most producers of today who operate in secrecy, it seems that filmmakers of the past had an open book policy. Going further on how funding of Nigerian films were conducted, Adesanya says that before the advent of capital market financing, funds for film production were sourced through government, foreign grants/co-production, private investors (ñAngelsò or ñRish Unclesò in industry parlance), local film distributors/exhibitors, and sometime in the 80s, the Nigerian Film Corporation (NFC); and before it the Nigerian Film Distribution Company (NFDC)... Through the NFDC/NFC, the federal government provided financial soccour for films by Hubert Ogunde, Moses Olaiye (Baba Sala), Adeyemi Afolayan (Adelove), Awada kerikeri Organization (AKO) et al (1990, p.1 \&2).

The above outlines a methodological roadmap to film funding, which has over the years dwindled in spectrum and zeal. These days, individual producers working in concert with family and friends are left at the mercy of chance. Independent producers, rather than Government and Corporate entities, are at the forefront of filmmaking in Nigeria, with little or no assistance from the Government. This has not always been the case as Adesanya reports that the Nigerian Film Corporation (NFC) was favourably poised to

Usually, the NFDC/NFC grants each film project a loan of about N100, 000. On the average, before SAP, a Nigerian feature film was produced for between N300, 000 and N500,000. With the introduction of SAP and Capital Market Deregulation, it now swings between $\mathrm{N} 1 \mathrm{~m}$ and $\mathrm{N} 2.5 \mathrm{~m}$. as a result of its inability to recover outstanding loans, the NFDC/NFC has found it impossible to advance loans to local film makers since mid-80s. The NFC has now shifted its attention to in-house productions and support for books on the Nigerian film sceneé During the era 
of foreign exchange approval, the NFDC assisted the likes of ola Balogun. Eddie Ugbomah, AdeLove, Ogunde, Baba Sala, Moyo Ogundipe to secure forex allocation at the CBN. (1990, p.2)

A critical outlook at the modus operandi of the early film industry in Nigeria depicts a well-articulated endeavour at assisting local producers to financially offset the burden of movie making. The climate has changed drastically and the demand for foreign exchange is even higher but the mechanism of state is not disposed to the course of Nollywood, even now that it seems demand for local content is becoming bigger. Perhaps it is better to remember that funding means that a filmmaker, before he began principal photography, has surmounted the hurdles of a befitting budget. This is because, the budget, apart from serving as a blueprint a filmmaker will follow to deliver a logically entertaining feature to the audience, has the inherent ability to moderate the course and content of a film. It is in this light that Yankov asserts that, in order to make a film: one of the most intuitive factors is undoubtedly the production budget. The simple logic states that the higher the production budget is the more revenue should be expected. There could of course be a base for endogenous relationships with some of the other factors that are described. For instance, a higher budget would allow more talented actors. Simultaneously, the more famous actors enclosed to the project, the better the chance to find more funds and to increase the production budget (2013, p. 48).

In the above argument, Yankov draws attention to the importance of a filmôs budget. This is considered given its capability to assemble the best cast, especially with reference to star actors and their inherent predisposition to woo investors. In most cases, maybe where star actors pledge allegiance to a project, they use their stardom profile as collateral to woo prospective investors. Myers and Majluf identified three sources of funding such as: Internal funding, Debt, and Equity. As explained, personal savings, plough backs, and capital generated without recourse to legal 
implications are classified as internal funding. At the level of this source of fund can be found, funds derived from family and friends and other media through which money may be raised for a given project. Likewise, Debt is explained as a formal agreement between two or more parties who contractually share wealth in the interim with the hope of getting back the principal with some form of interest. Banks and mortgages or lending institutions needing collateral specialize in this form of funding. Equity, on the other hand, involves a state of fund acquisition in which the partnership between an entrepreneur and an investor is solely based on the latterôs monetary abilities. With regards to motion picture production, equity is explored as a co-production factor either on an international scale, or between individuals (1984, p. 194).

Internal funds are also commonly known as non-formal debt and equity. Internal funds include founders investing their own money into their start-up or gaining funding through friends or family. Formal ñdebt financingò can be defined as money being borrowed on credit that you look to repay in the future, in full including interest. Formal equity financing is money obtained from an investor, which could either be angel investors or venture capitalist firms (Hann and Hinloopen, 1999, p. 577). This is based on the principle that, firstly corporations prefer internal financing; secondly, debt financing; and thirdly, prefer new equity financing. What this implies is that these preferences are based on the fact that the cost of financing increases with inability of investors to determine the financial state of the benefitting firm. An informal type of financing, commonly used by start-ups, is bootstrapping, which can be defined as the use of creative strategies to gain control over resources (Harrison et al., 2004, p. 17) or strategies that obtain resources without external financing (Freear et al., 1995, p. 29).

The following comprise other viable and varied sources from which film producers can access funding for every film venture. For example; Bootstrapping financing may include sharing resources, taking out personal loans, which are then inserted into the start-up or going without some common essentials 
to help pay for start-up costs (Winborg and Landstrom, 2001, p. 238). Another category of financing is ñquasi equityò. This fills the gap between equity and debt financing. Quasi equity is characterised by both debt and equity. Sometimes, it is also commonly referred to as revenue participation investment. It is usually structured as investments where the financial return is calculated as a percentage of the investeeôs future revenue (Cheng, 2008 , p. 1). Grants are another type of funding source commonly used to fund film production in Nollywood. Grants are often described as ñfree moneyò. There is no interest on grants and the provider of the fund does not take an equity stake or claim over the company. Sources, such as central, regional, or local government, provide companies with grants. One of the biggest disadvantages of a grant is that it takes a lot of time and effort to complete a grant application. Samoylova categorizes grants as a type of formal equity (2014, p. 9). Reflected in the 2011 subvention, through the Bank of Industry, the production of Dr Bello by Tony Abulu attests to how government grants can elevate the film production business in Nigeria. While the Association of Movie Producers kicked against the difficult requirements attached to accessing the grant, it is good news that business-minded filmmakers have a source of funding to tap from. In 2013 also, the administration of President Goodluck Jonathan instituted a Film Production Fund (FPF). So far, it has awarded 32 film producers with grants from the FPFठ a N700 million instrument, which allocates grants to production companies as part of the N3 billion Presidential Intervention Fund for the Nigerian movie industryð project ACT Nollywood (This Day, 20 ${ }^{\text {th }}$ July, 2014).

According to Samoylova a number of studies have concluded that personal funds were the initial source of funding for a majority of start-ups. Based on this, there are empirical evidence to prove that as firms mature and became less secretive with investment-friendly information, they are able to attract external funding, such as angel investors. Secondly, the longer a start-up firm is able to survive on its own with personal funds, the lower the cost of external capital and, hence the more control retained by the entrepreneur (2014, p. 11). This shows that the first capital 
source used by entrepreneurs to fund their start-up is typically through either inserting their own personal fund or generating funds from friends or family. There are a number of reasons for this, and the most common reason is the difficulty involved in accessing other means of funding and founders wanting to keep control within the internal team (Bhide, 1992, p. 114). Myer and Majluf, therefore, assert that founders also use their personal funds to indicate their commitment in their start-up to potential investors, thus the use of internal funds can be a stepping stone to external funding (1984, p. 194).

To Nofsinger and Wang, family and friends are less worried about investor protection due to their connection to the entrepreneur, which reduces the risk of the investment therefore making the investment process less complicated (2009, p. 5). An example of this is that friends and family tend not to use a term sheet when making an investment. Samoylova states that Angel investors used to be quiet about their investments and searched for deals in secret. Due to the expanding growth of the angel industry, angels are becoming less secretive, though they are still somewhat private about their activities (2014, p. 16). Due to this, more Angel funding is available and more start-ups are aware of angel investment and its benefits to start-ups. Angel investors are individuals who have available funds and are ready to invest in an entrepreneurôs ideas. They are professional investors who specialize in investing in profitable start-ups (Nofsinger and Wang, 2009, p. 7). Recounting how Angel investment has been particularly auspicious in her filmmaking career, renowned Nollywood producer turned director; Emem Isong-Misodi tells Okachie that after making films they were bought from her by a marketer. In her words, ñWhen I finished I went to see him and he bought the movie outright from me. He said, I like the way you work, why donâ we work together? So he provided the funds for Emotional Crack that was when I really had funds; he believed in me and gave me whatever I want to shoot movie without asking or cutting corners (2011, p. 18)ò. Those who know the true picture of the funding hurdles that filmmakers encounter would immediately 
find her testimony too easy, but Emem Isong made the above statement in year 2000. She adds that ñfor about six to seven years, we were making movies together. I made huge successful movies for himò. Whether this has become a partnership (equity), the truth remains that through this means, Emem Isong was able to fare favourably with her contemporaries. In Adesanyaôs opinion, the Nigerian film industry has always benefitted from Angels. This detail is available in his evaluation of funding sources for some known films during the 1980s:

ñAngelsò such as Fagbure, MKO Abiola (BISI), N.O. Idowu, Dantata (MAITATSINE), Doyin Investments (most of Ade-Loveô films), H.K. Aderibigbe \& R.N. Aggrey (VIGILANTE), R.A. Ladoja (IWA), Kunle Balogun (Fopomoyo \& Ofa Oro) et al have been responsible for the brothers., Ajileye etc. with perhaps the exception of Ladi Ladebo (coproducer of BISI), who had actually made his mark in New York before his local debut (1990, p.2).

In the above quote, it is apparent that early Nigerian films were fortunate as they received funding from notable individuals who supported the making of Nigerian films. This effort and many more served as great financial boost to the industry which strived to maintain a culture of quality productions as the era; 1970-1986 was known as the classical era of indigenous Nigerian films. Today however, Nollywood productions are marred with funding quagmire as it operates a production system that relies on itself for its continued survival in spite of viable avenues for funding.

Samoylova says that various researchers state that angel investment is the most important source of funding for start-ups because they generate useful resources to start-ups (2014, p. 12). According to Freear et al. Angel funding falls in between informal funding, such as founderôs funds, friends and family, and venture capital (1995, p. 279). Due to the fact that most entrepreneurs want to maintain control, the biggest problem is not accessing funding, 
but reducing reliance on external finance (Bhide, 1992, p. 113). Start-ups also find it hard to raise funds because of their limited knowledge of the investment process. Therefore, they may not be aware of the funding options available to them and may also not know how to develop an attractive investment proposal. This is because lack of exit opportunities for investors is a significant problem that constrains sources of start-up, and growth capital (Samoylova, 2014, p. 12). Due to the fact that a large amount of money needs to be raised and gaining external funding from sources such as banks is unlikely for start-ups, founders often find unique ways to raise money for their start-up. A study conducted in the United States stated that one such effective way of getting funding is through a bridge business (Samoylova, 2014, p. 14). Regarding the idea of a bridge business as a modest means of funding, it is on record that foremost Nollywood producers were electronics merchants and spare parts dealers. Even today, most of the executive producing in the Nollywood industry comes from investors whose primary profession is not filmmaking. John McCall reveals that: ñIn 1992 Kenneth Nnebue, an Igbo business man who had helped finance some of the Yoruba productions, wrote and produced the first Igbo language video, a ritual tinged movie called Living in Bondage. Two years later Nnebue made a flashy morality tale called Glamour Girls. It was the first English language video feature, and its success moved the industry out of the ethnic enclavesò (2004, p. 99-100).

Another main source of funding that has been established is ñcrowd fundingò. Crowd funding involves raising money directly from a large number of people who have invested significant amounts of funds. In Samoylovaôs view, there are number of online platforms that make crowd funding possible. A popular New Zealand crowd funding website is r̃Pledgemeò. Two other funding options that have recently been developed in a number of countries is ñequity crowd fundingò and ñpeer-to-peer lendingò also known as ñdebt crowd fundingò. These funding sources make it possible for start-ups to access some funding in the course of realizing their business idea. Before these funding sources were available, start- 
ups found it extremely difficult to gain debt funding from banks, due to their lack of collateral and insufficient cash flows. Also, there were a limited number of people and organisations, such as Angel and Venture Capital investors that start-ups could approach when looking for equity funds (2014, p. 14).

The principle of consumers pooling their money together in order to support a specific project initiated by someone else, is referred to as crowd funding (Harms, 2007, p. 3). Essentially, Harms states that (i) the principle of crowd funding can be used as an approach to finance the provision of public goods (ii) the principle of crowd funding uses the proven mechanism of crowd sourcing. While crowd sourcing focuses on pooling labour resources, crowd funding pools another factor of production: capital (iii) the principle of crowd funding is a further step of consumer involvement in the production process (iv) the principle of crowd funding uses the idea of social finance which found global recognition with the award of the Nobel Prize (2007, p. 8).

In Harmsô submission ñCrowd funding can be used for a variety of purposes. It can be used for group purchase, political campaigns, disaster relief, support of artists, starting up a business. There are popular examples where groups of several hundred people pool money together to finance the $\mathrm{CD}$ production of a musician or the production of a movieò (2007, p. 8). Li-ju Chen and Shun-yu Chen state that firms prefer to use their earnings to finance business activities and use less debt capital. For this purpose, firms choose capitals according to the following preference order: internal finance, debt, and equity. This is in line with Myers and Majlufôs 1984 assertion regarding the existence of information asymmetry between managers (insiders) and investors (outsiders) (2014, p. 1).According to Hutchinson, an announcement of increasing capital structure events is received by the market as good news because financial intermediaries like investment banks can become insiders to monitor the firmô performance. Managers may have internal information that is not known to the market. Insider investors have more information about the true distribution of firm returns than outsiders. Insider investors tend to limit the use of equity in order to retain control of 
the firm (1995, p. 231). According to Gaud et al. transaction costs play an important role in a firmôs capital structure decision. Transaction costs associated with obtaining new external financing are higher than the costs of obtaining internal financing (2005, p. $51)$.

According to Vidal and Ugedo, capital is a critical resource for all companies. The capital resources can be divided into two main categories, namely equity and debt. Equity arises when companies sell some of its ownership rights to gain funds for operation and investing activities. Debt is a contractual agreement in which companies borrow an amount of money and repay it with interest within a stipulated period (2005, p. 341). Bos and Fetherston assert that Pecking Order model is an important theory in the study of corporate capital structure that explains the relevance of debt and optimum capital structure inherent in a firm. This follows Myersôassertion that firms prefer to retain earnings as their main source of funds for investment, followed by debt. The reason for this ranking is that internal funds were regarded as ácheapô and as such, not subject to any outside interference. External debt was ranked next as it was cheaper and has fewer restrictions compared to issuing equity. The rationale being that external equity is seen as the most expensive and dangerous. It can lead to potential loss of control of the enterprise by the original owner and manager, hence, it was ranked the last (1993, p. 577).

\section{Invasion 1897: Plot Review}

The story opens on a gory note in the ancient Benin Kingdom in the year 1897 where two men are butchered. It turns out that it was a dream by the crown prince of Benin Kingdom who, waking up from his sleep decided to alert his father, the Oba at the palace. Upon meeting with his father and telling of his dream, which he captions a rain of fire; there is a transition scene to London in the year 2014. This establishes a century apart from the ancient Benin Kingdom to a UK University where a Benin Prince is in a History class listening to a Professor who delivers a lecture about a telegraphic stool once used by Oba Ovonramwen of ancient Benin Kingdom when he was exiled by the British to 
Calabar. The Professor then invites the Prince to one of his lecture series on African history where Benin cultural artefacts were highlighted and their historic, socio-cultural significance fascinated the Prince. Intrigued by the rich cultural heritage of his people of the Benin Kingdom, the Prince decided it was high time he took the history of his ancestors more seriously. As part of the African history tour being given by the Professor of history, they visited the British museum where the Prince decided to hide until everyone left the building before he attempted to smuggle all artefacts of Benin origin from the display platform.

In an attempt to cart away the Benin artefacts from the British Museum, the alarm security system triggers leaving the Prince at the mercy of British police. The law enforcement officers apprehend and charged the Prince to court the following morning. Arraigned before a judge in a London court, the Prince faces a judge and pleads not guilty, explaining that he could not have stolen what belongs to him. He illustrates by referencing the judgeôs wig when he quizzed her, saying should she find out that her gown and wig were missing and finds them somewhere whether she would not take it. The judge answers in the affirmative and so the Prince narrates how the British, in 1897, invaded the ancient Kingdom of Benin, carted away precious artefacts and killed scores. This narration transits to ancient Benin kingdom where we see in montages, Igun bronze casters making their art works. From Benin, we are introduced to the British Colonial post at Sapele where Consul Galwey informs Hamilton, his assistant that they will have to make a journey to Benin where, as they have been duly notified by their trading partners, there exists a large deposit of rubber.

Galweyố overtly ambitious assistant prays his boss for them to take the land by force if the Oba dares stand in their way. In several shots which follow, much is revealed about the peace in the land by depicting youths in moonlight tales and revelling in their youthful exuberances. The montages reveal that until the arrival of Consul Galwey and his men to Benin, the situation in Benin Kingdom was stable. The British, responding to the Obaôs questions, makes a case for the death of seven unarmed British 
Soldiers. To drive home his point, Moore says the Oba will be tried in accordance with modern laws. Thereafter, he offered the Oba the position of Paramount Chief in the new British Government which he Ovonramwen rejected. Obaseki, seeing that the British have sacked Benin kingdom and its monarchy, requested that he be given some authority so as to bridge the gap between Colonial interest and the wellbeing of Benin kingdom. Following this understanding, upon the Obaôs exile, the flashback ends and reveals present event happening in 2014. The audience returns to modern civilization in London, United Kingdom where the Prince completes his narration of British conquest of Benin. The Judge, guided by reason, after evaluating the sense in the narrative, acquits and discharges the Prince with an admonition to seek justice in a higher court of jurisdiction for the stolen artefacts to be returned to Benin City, the present capital of the ancient Kingdom of Benin, in present day, Edo State.

What is notable in the making of the film is its sources of funding resulting from the angel and product placements sponsorship the production received. On a closer note, the sentiments pervading the historical relevance of the story and the need to re-write the historical sanctity of the Benin race by the financiers call our attention to the fundamental implications of funding to the content, prestige and form assumed by Invasion 1897.There is so much one can learn from historical records, such that while is it expedient to capture this same material on film for the purpose of informing, educating, entertaining and celebrating our rich cultural heritage, there is some material to reference for posterity. By this is meant that it is not just enough to source materials for drama production from historical records and replicate history all over again, but it behoves on the theatre producer to bring in a viewpoint which can clearly distinguish history from art. This is made possible by the sources of funding a theatrical production receives and to what extent its intentions are aligned. The funding provision by Senator Daisy Ehanire Danjuma and Captain Hosa Wells Okunbo, both an illustrious Bini son and daughter captures the essence of their heritage, a move geared 
towards the celebration of their ancestry. This way, the financial commitment and goodwill funding invested concretises the ideal of representing a historical Bini piece for all to see.

\section{Conclusion}

It is no news that Nollywood is challenged by the deep seated financial straits resulting from years of colonial policy and lack of articulated efforts to champion the prosperity of the Nigerian entertainment brand by the current administration. While not downplaying on other sources of funding apart from Government grants and subventions, there remains to be seen how an individual effort is capable of uplifting the commercial status quo of the Nollywood film industry. This is where corporate presence is a must for Nollywood to transcend its comfort zone and compete like its counterparts abroad. The possibility of a virile Nigerian film industry is totally untenable due largely to its inability attract international collaboration between owners of big budget film studios and indigenous producers. The implications of relying on internal funding are that Nollywood will continue to churn out shoddy productions and remain elusive to the prospects of breaking even at the cinemas. For the best to happen, it is expedient for producers to pull resources together under an aegis that is formidable enough to attract foreign direct investments. As discussed above, there are numerous sources from which filmmakers can resort for production purposes but one particular case is the prospects of product placements. Recent cinema outing in the Nigerian context has shown that quite a number of producers, as it is the case in other parts of the world, receive an upfront of $30 \%$ of their production capital integrating brands in the context of their scripts, blending audio-visual elements as a tie-in for their events enactment. In some climes, this recourse is seen as the new avenue for advertisement because of the exorbitant rates of traditional commercials. In the Nollywood phenomenon, it is envisaged that a synthesis of all funding sources will not only be auspicious but affect the manner in which indigenous stories are produced. In order to succeed at this, it is essential that through 
government policies that Nollywood be taken beyond international premiers and film festivals. In addition, government agencies should be at the forefront of establishing and facilitation avenues for distribution and exhibition of indigenous Nollywood films home and abroad.

APPENDIX

AN INTERVIEW WITH LANCELOT ODUWA IMASUEN; CONDUCTED $1^{\text {ST }}$ JUNE, 2016. SURULERE, OFF ADENIRAN OGUNSANYA, LAGOS, NIGERIA

LANCELOT: Director/Producer-INVASION 1897 (2015)

Interviewer: Ok, we are here. Good morning sir and the questions are 1. What is your take about Nollywood funding?

LANCELOT: Well, I think, a lot of us are more bothered about structures. By structures I mean how we get back whatever funds we ply into Nollywood. So, the Nollywood funding, the way we see it, is not structured at all. But recently, some corporate bodies like the Banks have started looking at how Nollywood can be funded. The likes of the Intervention Banks, BOI (Bank of Industry) started from the era of President Goodluck Jonathan who realized that oh, these people need some kind of corporate funding. But before then, Nollywood was strictly funded on the basis of óMan Know Manô phenomenon. It is either youôe selling your properties if you want to make a film or youôe looking for an Uncle, producer or ómoney bagô around you. In this kind of scenario, you find out that because things are not being handled the way it out to be, for the reason that Nollywood lacks structures, it becomes a herculean task to come by funding. If it were not so, producers would have a place to go in order to access funding for their film projects.

Interviewer: Ok, thank you sir. So how much is enough to make a film for the Nigerian cinemas?

LANCELOT: Well, I think that is not the right way to ask that question because that is not tenable at all, there is nowhere in the world where one can say an actual sum begets a type A or type B film. Truth is, with a million naira, one can make a good film that 
people will appreciate, in the same vein, you can also spend a hundred million naira and people will not appreciate it. So, I donâ think your question is something one can verify because, saying that how much is enough negates the fact that nothing is too big or small. Matter of fact, there is no amount that is too small. Well, there are basic requirements that you expect a film to have. If you want to do a film for the cinemas, it will take some time and have cinematic qualities but one must be ready to invest heavily too. But to say that this amount is pegged for a film because it will be listed at cinemas is really arguable. However, spending depends on the kind of story you are telling and the kind of movie you want to make.

Interviewer: So, sir, in what way can an average producer raise funds for films?

LANCELOT: Well, if you ask me again, I think I already enumerated that when I mentioned Uncles, Money Bags, country man and woman, friends, yourself, those that are courageous enough can go take loans from Banks with skyscraper interest rates. In Nigeria, funding is more like a family thing unless one is self-sufficient.

Interviewer: Ok, thank you for reiterating the above points. I want to know sir, what was the Edo State Governmentôs role in the making of INVASION 1897 ?

LANCELOT: Nothing! Completely nothing! They did not contribute a dime! Not even logistical support.

Interviewer: Sir, Senator Daisy Ehanire Danjuma (a former Edo South Senator and Wife of Gen. Theophilus Danjuma) and Hosa Wells Okunbo were credited as Executive producers, can you give an estimate of how much they invested in the production of INVASION1897?

LANCELOT: Well, the expenditure comes like this: Daisy Danjuma funded the actual filmmaking while Wells Okunbo facilitated the logistical services including movement of cast and crew for London set shooting, Premiers in Benin, Lagos, Canada, London and Washinton DC.

Interviewer: So, sir is it possible to give an estimate of the figures it took to make Invasion 1897 ? 
LANCELOT: Well, INVASION 1897 as a movie, we spent over sixty to eighty million (N60, 000, 000-80,000,000)

Interviewer: naira?

LANCELOT: Yes, naira.

Interviewer: well, I know that because of the time frame as a result of your pre-planned trip sir, will it be difficult to enumerate the actual amount you gave the cast or would you rather give an estimate?

LANCELOT: if I understand you very well because we spoke yesterday, set and props for INVASION 1897 was about three million six hundred thousand naira $(3,600,000)$, costume was up to three million naira $(3,000,000)$, special props was about a million two hundred thousand $(1,200,000)$, hotel bill was about eight million $(8,000,000)$, transport and movement gulped about three million $(3,000,000)$ because we shot for about thirty one (31) days because we stayed in like seven different hotels. Artistesôfee was about thirty percent of the entire budget. As I said earlier, logistics was handled by Hosa Wells Okunbo but post production gulped about eight million naira $(8,000,000)$ because the editing, some which was done here was not so impressive and we had to fly an expatriate editor from the London, the person was here for a couple of weeks and finally ended up in a studio in Burbank, Los AngelesCalifornia, USA for additional editorial services. For this trip, four thousand dollars $(\$ 4,000)$ was expended for flight tickets and hotel bills.

Interviewer: So, sir how well did Invasion 1897 do at the cinemas, both home and abroad, so far?

LANCELOT: well, so far, out of the money we put in the film, only thirty million naira $(30,000,000)$ has been made. In spite of the fact that it was well talked about and everyone we met seem to appreciate its content, this has not translated into monetary gains. This is why we actually need more structures on ground for a virile Nigerian cinema culture. The aim is to be able to trace sales of our films because truth is, most people make losses. A whole lot is not talked about, in terms of the marketing dynamics; so much is lost when it concerns recouping oneôs investment. 
Interviewer: sir, if you visit video shops now, you would have noticed that your film INVASION 1897 is on sales. How do you track the sales?

LANCELOT: We have a distributor who gives us feedback on sales. Off course, you know the perennial piracy problem. This is the major challenge we have as filmmakers in Nigeria.

Interviewer: So, should you have the power to make things right in the Nollywood sector of the Nigerian economy, regarding funding, what would you do?

LANCELOT: what I will first make right is the end point. The end they say justifies the means. The end point of recouping whatever investments one has pulled into the making of a film. Once people are very sure of a standardized recoupment process funding will not be a problem. There are Banks that are ready to dole out money; Access Bank just announced its NollyAccess loan scheme for filmmakers, BOI (Bank of Industry) and others are there. If really we can do this as business, there wonâ be the problem of funding. Basically, my fear right now, is that we are still having a lot of problems as it regards funding; I mean funding generally and not with specific reference to productions alone. We need structures, we need more cinemas, and we need National Orientation Agency programmes encouraging more Nigerians to patronize Nigerian films. We need a holistic approach for the sales of Nigerian films so that they can compete favourably with their foreign moviesô counterpart that you see everywhere in the Country. There is this apathy by Nigerians all around about Nigerian films (mimics: aahaahhh all this Nigerian films, abeg jor). Government should seriously step in and realign the peoplesô social consciousness to be friendly with indigenous films. That is where we need funding more, not even in productions because once these things are there, once the structures are there, not boxoffice breaks which comes as óne-off. Run-offô that are not consistent in terms of availability and people notice that good films are getting by at the cinemas, and other structures are there, funding will come.

Interviewer: Then sir, do you agree that the more a filmô budget the better its quality? 
LANCELOT: Well, you cannot underplay that the more money you have invested in a film the more you want to actualize. However, that has never guaranteed sales that is the point I want to make. Then, it is a statement of fact that the more money you have the more quality you can exude in your productions if you know what you are doing. This means the more value your film will have with regards to its artistic, technical and commercial content and context. This will augur well for you if you are not trying to cut corners and maximize little or no adequate budget. You need an aero plane, you go to get it, even in the airport you go to get the license, whatever you need, and you get it because your budget suffices for it. This is especially critical in enhancing the production value but how it is applied now from the creative aspect is another angle entirely for another day. Quite frankly, when you hear that so so and so film is a two hundred million dollars $(\$ 200,000,000)$ production, you will see it in the film. When you hear, this is a fifty million naira $(\mathrm{N} 50,000,000)$ production you see it in the film and that is my take.

Interviewer: Thank you so much sir. But sir, there is still one issue although it is not part of my study, it concerns giving information about Nollywood. For the past three years I have suffered the problem of information hoarding in this Industry. It is difficult for me to meet someone like you and you tell me, ok in this my film, I invested such an amount, is it because producers are not willing to divulge the amount they invested or government will come after them for tax purposes?

LANCELOT: No, it is not about government. This question takes us back to my earlier point about structure. In other climes, you do not even have to go chasing filmmakers for details of their production budget, all you do is visit the productionôs website and retrieve whatever information you require. That, my brother, is how structured industries are run-transparent and everything wellarticulated because they know news makers and researchers would want to write about these things. So, it simply comes back to lack of structure in Nollywood. If you go to most film websites in the US and Google film budget for a particular film, it will pop up, 
they donâ hide anything. But here, it is a process we need to go through, so you find out that there is need to chase producers to get basic information but with time all these will change.

\section{References}

Aabi, M. (2014). The pecking order theory and SMEs financing: Insight into the Mediterranean area and a study in the Moroccan context. The International Journal of EuroMediterranean Studies,7 (2), 189-206. www.emuni.si/press/ISSN/1855-3362/7

Adesanya, A. (1990). ñBottom-lineò The Guardian (on Sunday), Lagos. Bhide August 26, A. (1992). Bootstrap finance-The art of start-ups. Harvard Business Review, 70, 109-117. www.amozon.com/management\&leadership

Bos, T. and Fetherston, T.A. (1993). Capital structure practices on the pacific rim. Research in International Business and Finance, 10, 53-66. www.academic.edu/7683163/Capitalé

Cheng, P. (2008). Quasi equity. London: Charities Aid Foundation. www.cafonline.org/venture-some-Quasi-Equity-pdf/.

Ekwuazi, H. (1987).Film in Nigeria. Ibadan: Moonlight.

Freear, J., Sohl, E. and Wetzel, E. (1995). Who bankrolls software entrepreneurs? Frontiers of Entrepreneurship Research, 16 (4).www.emeraldinsight.com

Gaud, O., Jani, E., Hoesli, M. and Bender, A. (2005). The capital structure of Swiss firms: An empirical analysis using dynamic panel data. European Financial Management, 11, 51-69.

www.archive-ouverte.unige.ch/unige: 36955

Hann, L. and Hinloopen, J. (1999). Debt or equity? An empirical study of security issues by Dutch companies. Econometric Research and Special Studies Department, 577.

www.yadda.icm.edu.pl/yadda/element/bwmeta1.element.ekon... 
Harms, M. (2007). What drives motivation to participate financially in a crowd funding community? www.crowdfunding.de/wpcontent/.../crowdfunding-Master-Thesis-Michel- Harms

Harrison, T., Mason, M. and Girling, P. (2004). Financing bootstrapping and venture development in the software industry.

Entrepreneurship and Regional Development.307-333 www.academic.edu

Hutchinson, R.W. (1995). The capital structure and investment decision of the small owner-Managed firm: some exploratory issues. Small Business Economics, (76), 231239.

www.jimsjournal.org/10\%20Li-Ju\%20Chenpdf.pdf

Li-ju C. and Shun-yu C. (2014).How the pecking order theory explain capital. Taiwan: Cheng Jung Christian University.1-9

www.jimsjournal.org/Li-ju/Ch

McCall, C. J. (2004). Nollywood confidential. Transition, (95), Indiana: Indiana UP. 98- 109. www.researchgate.net/.../236695691_NollywoodConfidential

Myers, S. and Majluf, N.S. (1984). Corporate financing and investment decisions when firms have information that investors do not have. The Journal of Financial Economics, 13, 187-221.www.nber.org/papers/w1396

Nofsinger, J. and Wang, W. (2009). Determinants of start-up firm external financing Worldwide. Washington: Pullman. www.clevelandfed.org/

Okachie, L. (2011, January $\left.22^{\text {nd }}\right)$. I shot my first movie with N60, 000 ï Emem Isong. Saturday Champion, Lagos.

Samoylova, A. (2014). A High-tech start-ups journey towards funding.1-98, M.ATE,

http://researcharchive.vuw.ac.nz/xmlui/bitstream/handle/10063/36 $\underline{84 / \text { thesis.pdf? sequence }=2}$

Vidal, J.S. and Ugedo, J.M. (2005). Financing preferences of Spanish firms: Evidence on thepecking order theory. Review of Quantitative Finance and Accounting, 25(4), 
341-355.http://link.springer.com/article/10.1007/s11156-

005-5459-6

Winborg J. and Landstrom, H. (2001). Financial Bootstrapping in Small Businesses: Examining Small Business Managersô Resource Acquisition Behaviours. Journal of Business Venturing, $\quad 16, \quad 235-254$. isb.sagepub.com/content/30/6/659.refs

Yankov, N. S. (2013). Producing a feature film: An Overview of the Industry, the Process and The Factors affecting the financial performance of a motion Picture. Aarhus University:

Business and Social Sciences. www.pure.au.dk/... 